\title{
PEMANFAATAN GOOGLE SCHOLAR DALAM MENDUKUNG PERSIAPAN SISTEM PEMBELAJARAN E-LEARNING DI POLITEKNIK ILMU PELAYARAN MAKASSAR
}

\author{
Makmur, Rukmini, Agustina Setyaningsih, Andi Asnita \\ Novyanti, Gradina Nur Fauziah
}

\author{
Politeknik Ilmu Pelayaran Makassar \\ Jalan Tentara Pelajar No. 173 Makassar, Kode pos. 90172 \\ Telp. (0411) 3616975; Fax (0411) 3628732 \\ E-mail: pipmks@pipmakassar.com
}

\begin{abstract}
ABSTRAK
Penelitian yang bertujuan mengkaji pemanfaatan Google Scholar di Politeknik IImu Pelayaran Makassar ini dilaksanakan dalam rangka mendukung proses persiapan penerapan sistem pembelajaran e-learning di Politeknik IImu Pelayaran Makassar. Selain itu riset ini juga mengkaji tingkat penguasaan Google Scholar di Politeknik IImu Pelayaran Makassar. Lokus penelitian adalah Kampus II Politeknik IImu Pelayaran Makassar. Kampus II berlokasi di jalan Daengta Qalia, Salodong, Kecamatan Untia, Kota Makassar. Metode yang digunakan dalam penelitian ini ialah metode analisis deskriptif. Teknik ini digunakan untuk memberikan gambaran umum data penelitian dan mendeskripsikan karakteristik responden. Sementara metode yang digunakan dalam pengumpulan data adalah melalui metode dokumentasi dan metode kuesioner. Sample penelitian berjumlah 59 orang taruna yang duduk di kelas Teknika IIIE, IIIF, Nautika IIIF, IIIG dan lulus seleksi pada tahun ajaran 2017/2018. Hasil penelitian ini menunjukkan bahwa jumlah penggunaan Google Scholar adalah cukup banyak. Atau dengan kata lain sebagian besar (24 orang sample dari 59 orang populasi) atau 40,68\% responden memilih jawaban tersebut. Hasil penelitian juga menunjukkan bahwa tingkat penguasaan Google Scholar di Politeknik Ilmu Pelayaran Makassar adalah cukup mahir. Artinya sebagian besar responden yang berjumlah 26 (dua puluh enam) orang atau $44,07 \%$ memilih jawaban tersebut.
\end{abstract}

Kata kunci: Pemanfaatan, Google Scholar, Tingkat Kemahiran 


\section{PENDAHULUAN}

\section{A. Latar Belakang Masalah}

Kebutuhan taruna Politeknik IImu Pelayaran Makassar akan ilmu pengetahuan dan informasi yang tinggi menuntut adanya media yang cepat dalam menyajikan pengetahuan dan informasi yang akurat. Hal ini membuat taruna cepat tanggap terhadap permasalahan yang terjadi. Beragam aplikasi internet telah menyediakan layanan yang dapat memenuhi kebutuhan tersebut, utamanya Google. Namun sayangnya Google seringkali menghubungkan penggunanya dengan situs-situs yang kurang relevan. Sehingga menghabiskan waktu yang lama untuk mencari literatur yang dibutuhkan.

Salah satu aplikasi di Google yang dapat memecahkan permasalahan tersebut ialah Google Scholar. Aplikasi yang diperkenalkan pada tahun 2004 memiliki sumber informasi yang lebih akurat dibandingkan dengan aplikasi Google. Selain itu kelebihan dari aplikasi ini ialah memudahkan untuk mencari literatur akademis berupa jurnal - jurnal ilmiah, thesis, makalah peer-reviewed, artikel, abstrak dan buku dari sumber - sumber yang menyediakan informasi yang relevan. Aplikasi ini juga memiliki ribuan data dalam database sehingga sudah lebih dari cukup untuk menelusuri informasi mengenai tulisan ilmiah lainnya.

E-learning atau pembelajaran melalui sarana elektronik adalah sistem pembelajaran modern dalam proses belajar mengajar disekolah maupun perguruan tinggi. Untuk meningkatkan standar mutu pendidikan, e-learning menjadi salah satu media pembelajaran tambahan yang wajib digunakan dalam penyampaian materi pembelajaran. Hal terebut karena E-learning memiliki karakteristik yaitu: (1) Memanfaatkan jasa teknologi elektronik, dimana Pengajar dan Peserta didik, Peserta didik dan Peserta didik, ataupun Pengajar dan sesama Pengajar dapat berkomunikasi dengan relatif mudah tanpa dibatasi oleh hal-hal yang protokoler; (2) Memanfaatkan keunggulan komputer (media digital dan jaringan komputer); dan (3) Menggunakan bahan ajar yang bersifat mandiri yang dapat disimpan di komputer sehingga dapat diakses oleh Pengajar dan Peserta didik kapan saja dan dimana saja bila yang bersangkutan membutuhkannya. Perkembangan ilmu dan Information Communication Technology, proses dalam pembelajaran mulai bergeser pada proses belajar 
(learning), berbasis pada masalah (case base), bersifat kontekstual dan tidak terbatas hanya untuk golongan tertentu. Pada proses pembelajaran seperti ini mahasiswa dituntut untuk lebih aktif dengan mengoptimalkan sumber-sumber belajar yang ada, termasuk dalam hal ini melalui media Google Scholar.

Berkaitan dengan implementasi pembelajaran berbasis teknologi informasi dan komunikasi, terutama pemanfaat e-learning sebagai media pembelajaran alternatif, Politeknik IImu Pelayaran Makassar perlu melakukan analisis kebutuhan penggunaan media pembelajaran berbasis e-learning. Melalui E-learning seluruh dokumen perkuliahan Dosen dapat diakses oleh Taruna dan sebaliknya Taruna dapat menyelesaikan tugas perkuliahan cukup dengan mengirim file kepada Dosen yang bersangkutan, sehingga waktu perkuliahan menjadi lebih efisien. Disamping itu, e-learning juga memberikan kemudahan kepada Peserta diklat pada Politeknik IImu Pelayaran Makassar untuk mengakses informasi yang dibutuhkan. Namun diperlukan beberapa kajian pendukung implementasi sistem yang terhitung baru bagi peserta didik di Politeknik IImu Pelayaran Makassar. Dimana tentunya mereka membutuhkan referensi, informasi tentang model dan bentuk serta media pembelajaran e-learning yang secara optimal dapat dengan mudah mendukung proses e-learning. Munculnya keterbatasaan akses IT yang disebabkan oleh adanya ketentuan tingkatan semester yang membolehkan peserta didik untuk menggunakan laptop, mau tidak mau juga perlu mendapat perhatian khusus bagi percepatan mengejar ketertinggalan penguasaan media dalam proses e-learning.

E-learning tidak dimaksudkan untuk mengganti secara total kegiatan belajar mengajar yang selama ini berlangsung di Politeknik IImu Pelayaran Makassar. E-learning lebih difokuskan pada suatu kegiatan belajar mengajar alternatif untuk mendukung kegiatan belajar mengajar yang selama ini diterapkan. Salah satu aplikasi e-learning yang dapat diakses oleh baik Pengajar maupun Peserta didik adalah Google Scholar. Google Scholar merupakan aplikasi dari Google yang memungkinkan pengguna melakukan pencarian materi-materi pelajaran berupa teks dalam berbagai format publikasi. Referensi ini dapat berupa jurnal ilmiah yang merupakan hasil-hasil penelitian atau kajian yang dapat dipertanggungjawabkan secara ilmiah. Dengan adanya Google Scholar, mempermudah Peserta didik dalam menemukan referensi sebagai bahan materi pembelajaran. Berdasarkan latar 
belakang permasalahan tersebut, maka peneliti tertarik untuk mengangkat judul "Pemanfaatan Google Scholar dalam Mendukung Persiapan Sistem Pembelajaran E-learning di Politeknik IImu Pelayaran Makassar".

\section{B. Rumusan Masalah}

Ditinjau dari latar belakang masalah yang telah dipaparkan, maka dapat diidentifikasi beberapa rumusan masalah dalam penelitian ini sebagai berikut:

1. Seberapa besar pemanfaatan atau penggunaan Google Scholar dalam mendukung persiapan penerapan sistem pembelajaran elearning di Politeknik IImu Pelayaran Makassar.

2. Seberapa mahir tingkat penguasaan Google Scholar di Politeknik Ilmu Pelayaran Makassar.

\section{Tujuan Penelitian}

Penelitian ini dilakukan untuk mencapai tujuan sebagai berikut:

1. Mengkaji pemanfaatan Google Scholar dalam mendukung proses persiapan penerapan sistem pembelajaran e-learning di Politeknik Ilmu Pelayaran Makassar.

2. Mengkaji tingkat penguasaan Google Scholar di Politeknik IImu Pelayaran Makassar.

\section{Manfaat Penelitian}

Manfaat yang diperoleh dari penelitian ini adalah sebagai berikut:

1. Secara teoritis, penelitian ini bermanfaat untuk menambah sumber referensi penelitian dalam bidang pendidikan dan teknologi informasi.

2. Secara praktis, penelitian ini bermanfaat bagi Institusi sebagai bahan pertimbangan bagi institusi dalam mempersiapkan penerapan sistem pembelajaran e-learning. 


\section{TINJAUAN PUSTAKA}

\section{A. Pengertian Pembelajaran E-learning bagi Peserta Didik}

Pembelajaran mempunyai pengertian yang mirip dengan belajar, walaupun mempunyai konotasi yang berbeda. Dalam konteks pendidikan, tenaga pendidik memberikan pelajaran kepada peserta didik agar dapat menguasai isi pelajaran sehingga mencapai sesuatu objektif yang ditentukan (aspek kongnitif), juga dapat mempengaruhi perubahan sikap (aspek afektif), serta keterampilan (aspek psikomotor). Peran tenaga pendidik bukan semata memberikan informasi melainkan juga mengarahkan dan memberi fasilitas belajar (directing and facilitating the learning) agar proses belajar lebih memadai dan mudah diterima oleh peserta didik (siswa/mahasiswa). pembelajaran mengandung arti bahwa setiap kegiatan yang dirancang untuk membantu seseorang mempelajari suatu kemampuan atau nilai yang baru. Proses pembelajaran merupakan seperangkat prinsip-prinsip yang dapat digunakan sebagai pedoman untuk menyusun berbagai kondisi yang dibutuhkan dalam mencapai tujuan pendidikan.

E-learning adalah singkatan dari Elektronic Learning dan merupakan cara baru dalam proses belajar mengajar yang menggunakan media elektronik khususnya internet sebagai sistem pembelajarannya. Pembelajaran elektronik atau e-learning telah dimulai pada tahun 1970-an (Waller, 2001). Berbagai istilah digunakan untuk mengemukakan pendapat/gagasan tentang pembelajaran elektronik, antara lain adalah: on-line learning, internet-enabled learning, virtual learning, atau web-based learning.

Banyak pakar pendidikan memberikan definisi mengenai $e$ learning, seperti yang dipaparkan oleh Thompson, Ganxglass dan Simon dalam (Sanjaya, 2006) berikut ini, "E-learning is instructional content or learning experiences delivered or enabled by electronic technology". Kemudian Thompson juga menyebutkan kelebihan $e$ learning yang dapat memberikan fleksibilitas, interaktifitas, kecepatan, visualisasi melalui berbagai kelebihan dari masing-masing teknologi. Elearning merupakan pembelajaran yang menggunakan sistem online sebagai medium perantara di antara tenaga pendidik dan pelajar. Belajar online ini akan memudahkan kedua belah pihak, karena penyampaian materi ajar lebih cepat, mudah dan efisien dibandingkan dengan cara-cara yang lain. Tenaga pendidik dapat memberikan materi 
pelajaran lewat internet yang dapat diakses setiap saat dan dimana saja. Peserta didik juga tidak perlu harus selalu belajar di kelas untuk mendapatkan informasi mengenai materi yang ingin diperolehnya. Bahkan peserta didik dapat mengembangkan proses belajarnya dengan mencari referensi dan informasi dari sumber lain.

E-learning mempermudah interaksi antara peserta didik dengan bahan atau materi pelajaran. Demikian juga interaksi antara peserta didik dengan tenaga pendidik atau instruktur maupun antara sesama peserta didik lainnya. Peserta didik dapat saling berbagi informasi atau pendapat mengenai berbagai hal yang menyangkut pelajaran ataupun kebutuhan pengembangan diri peserta didik. Tenaga pendidik atau instruktur dapat menempatkan bahan-bahan belajar dan tugas-tugas yang harus dikerjakan oleh peserta didik di tempat tertentu di dalam web untuk diakses oleh para peserta didik. Sesuai dengan kebutuhan, tenaga pendidik atau instruktur dapat pula memberikan kesempatan kepada peserta didik untuk mengakses bahan belajar tertentu maupun soal-soal ujian yang hanya dapat diakses oleh peserta didik sekali saja dan dalam rentangan waktu tertentu pula (Siahaan, 2004).

\section{B. Google Scholar}

Google Scholar (bahasa Indonesia: Google Cendekia) adalah layanan yang memungkinkan pengguna malakukan pencarian materimateri pelajaran berupa teks dalam berbagai format publikasi. Indeks Google Cendekia mencakup jurnal-jurnal online dari publikasi ilmiah. Google Cendekia menyediakan cara yang mudah untuk mencari literatur akademis secara luas. Seseorang dapat mencari di seluruh bidang ilmu dan referensi dari satu tempat: makalah peerreviewed, thesis, buku, abstrak, dan artikel, dari penerbit akademis, komunitas profesional, pusat data pracetak, universitas, dan organisasi akademis lainnya. Google Cendekia akan membantu seseorang mengidentifikasi penelitian paling relevan dari seluruh penelitian akademis. Google Cendekia bertujuan menyusun artikel seperti yang dilakukan peneliti, dengan memperhatikan kelengkapan teks setiap artikel, penulis, publikasi yang menampilkan artikel, dan frekuensi penggunaan kutipan artikel dalam 
literatur akademis lainnya. Hasil paling relevan akan selalu muncul pada halaman pertama. (Ni Ketut Susrini, 2009).

Google Scholar adalah salah satu bagian dari pembelajaran elearning. Berbeda dengan Google Search atau Wikipedia yang lebih sering digunakan untuk mendapatkan materi kuliah atau sekolah, Google Scholar belum sefamiliar keduanya. Namun, hasil pencarian dari Google Search banyak yang mengarah pada blog yang dinilai kurang relavan. Sementara itu, Wikipedia juga kadang dianggap sebagai sumber yang kurang bisa dipertanggungjawabkan, dengan alasan tersebutlah sehingga Google Scholar diperkenalkan untuk membantu pencari informasi pada umumnya dan khususnya para pelajar (Valiant, 2013).

Google Scholar adalah mesin pencari yang dibuat oleh Google untuk menangani pencarian materi pendidikan yang didalamnya termasuk paper, skripsi, tesis, tugas akhir, makalah, jurnal, pendapat hukum, dan banyak lagi. Salah satu kelebihan Google Scholar adalah penggunaan situs-situs resmi universitas atau lembaga pendidikan untuk menampilkan materi pendidikan, makalah, dan laporan ilmiah lainnya sehingga isinya lebih relevan dan dapat dipertanggungjawabkan.

\section{Kerangka Pikir}

Google Scholar adalah salah satu bagian dari pembelajaran berbasis elektronik yang lebih sering disebut dengan e-learning. Elearning adalah singkatan dari Elektronic Learning, merupakan cara baru dalam proses belajar mengajar yang menggunakan media elektronik khususnya internet sebagai sistem pembelajaran. Dengan adanya pembelajaran e-learning diharapkan kepada peserta didik dalam hal ini adalah Taruna pada Politeknik IImu Pelayaran Makassar dapat lebih mudah mengakses hal-hal yang diperlukan dalam menunjang tujuan pendidikan yang diharapkan. Sehingga kerangka pikir penelitian ini dijabarkan, seperti ditunjukkan pada Gambar 1. 
Gambar 1. Kerangka Pikir Penelitian

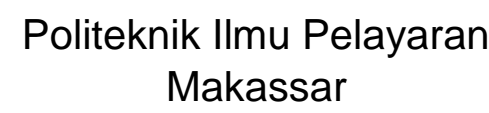

Pemanfaatan google scholar:

1. Penggunaan situs google scholar;

2. Penguasaan situs google scholar;

\section{Keterangan:}

Tempat Penelitian

Populasi penelitian

Variabel yang diteliti

\section{METODE PENELITIAN}

\section{A. Jenis Penelitian}

Jenis penelitian ini adalah penelitian deskriptif. Penelitian deskriptif adalah penelitian terhadap fenomena atau populasi tertentu yang diperoleh oleh peneliti dari subjek berupa individu, organisasi, industri atau perspektif yang lain. Penelitian deskriptif dilakukan untuk menjawab pertanyaan tentang apa, siapa, kapan, di mana, dan bagaimana yang berkaitan dengan karakteristik populasi atau fenomena tersebut. 


\section{B. Lokasi Penelitian}

Penelitian ini dilaksanakan di Kampus II Politeknik IImu Pelayaran Makassar.

\section{Definisi Operasional Variabel}

Adapun definisi operasional variabel dalam penelitian ini, yaitu pemanfaat e-learning dengan menggunakan Google Scholar adalah pengukuran berdasarkan tanggapan taruna mengenai sejauh mana pembelajaran dengan menggunakan sistem online sebagai media perantara diantara tenaga pendidik (dosen) dengan peserta didik (taruna) dengan menggunakan Google Scholar dengan indikator sebagai berikut:

1. Penggunaan situs google scholar

Variable tingkat penggunaan situs Google Scholar merupakan jumlah penggunaan situs Google Scholar dalam kegiatan pembelajaran di Kampus Politeknik Ilmu Pelayaran Makassar. Variable ini ditunjukan melalui jumlah skor penilaian responden taruna dari instrumen yang akan diberikan. Pemberian skor mengacu pada hasil jawaban atau penilaian responden terhadap jumlah penggunaan Google Scholar dalam pembelajaran di Politeknik IImu Pelayaran Makassar. Alternatif pilihan jawaban antara lain sangat banyak, banyak, cukup banyak, kurang dan sangat kurang. Prinsip pembobotan secara berurutan diberi skor 5, 4, 3, 2, dan 1 . Sementara untuk pertanyaan/pernyataan negatif kutubnya dibalik menjadi 1, 2, 3, 4, dan 5.

2. Penguasaan situs google scholar

Variable tingkat penguasaan situs Google Scholar merupakan tingkat penguasaan dosen dalam menggunakan Google Scholar sebagai media pembelajaran di Kampus II Politeknik IImu Pelayaran Makassar. Variable ini diukur dengan cara yang serupa dengan variable sebelumnya. Pemberian skor mengacu pada hasil jawaban atau penilaian responden terhadap penguasaan Google Scholar dalam pembelajaran di Politeknik IImu Pelayaran Makassar. Alternatif pilihan jawaban antara lain sangat mahir, mahir, cukup mahir, tidak mahir dan sangat tidak mahir. Definisi sangat mahir yang dimaksud di sini ialah dosen ataupun taruna benar-benar lancar menggunakan Google Scholar sendiri tanpa bantuan orang lain. Sementara definisi 
mahir di sini ialah dosen ataupun taruna mampu menggunakan Google Scholar sendiri tanpa bantuan orang lain. Definisi cukup mahir di sini ialah dosen ataupun taruna mampu menggunakan Google Scholar sendiri dan jarang membutuhkan bantuan arahan dari orang lain. Definisi tidak mahir di sini ialah dosen ataupun taruna tidak mampu menggunakan Google Scholar sendiri dan selalu membutuhkan bantuan arahan dari orang lain. Definisi sangat tidak mahir di sini ialah dosen ataupun taruna benar-benar tidak mampu menggunakan Google Scholar sendiri dan harus selalu dibantu orang lain.

\section{Populasi dan Sampel}

Populasi merupakan subyek penelitian. Menurut Sugiyono (2009) populasi adalah wilayah generalisasi yang terdiri atas obyek/subyek yang mempunyai kualitas dan karakteristik tertentu yang ditetapkan oleh peneliti untuk dipelajari dan kemudian ditarik kesimpulannya. Sehingga populasi dalam penelitian ini yaitu taruna pada Politeknik IImu Pelayaran Makassar yang saat ini duduk di kelas Teknika IIIE, IIIF, Nautika IIIF, IIIG yang secara khusus telah diajarkan untuk menggunakan aplikasi Google Scholar di mata kuliah teknologi informatika yang berjumlah 59 orang.

Sampel adalah bagian dari jumlah dan karakteristik yang dimiliki oleh populasi tersebut. Bila populasi besar, dan peneliti tidak mungkin mempelajari semua yang ada pada populasi, misalnya karena keterbatasan dana, tenaga dan waktu, maka peneliti dapat menggunakan sampel yang diambil dari populasi itu. Apa yang dipelajari dari sampel itu, kesimpulannya akan dapat diberlakukan untuk populasi. Untuk itu sampel yang diambil dari populasi harus betul-betul representatif (Sugiono, 2009). Pemilihan dan penetapan sampel dilakukan oleh peneliti berdasarkan waktu penelitian peneliti. Hal ini berarti teknik sampling pada penelitian ini menggunakan teknik sampling secara nonprobabilitas, yaitu teknik yang digunakan peneliti jika peneliti memiliki pertimbangan tertentu dalam pengambilan sampel atau penentuan sampel dengan kriteria tertentu dengan jumlah sampel di bawah 100 orang karena jumlah populasi tidak mencukupi 100 orang. Tim peneliti juga telah melakukan proses seleksi taruna yang memenuhi persyaratan khusus untuk mengisi kuesioner dan hanya 59 orang 
taruna yang lulus. Hasil seleksi inilah yang menjadi dasar untuk menetapkan jumlah sample dalam riset ini, yaitu sebanyak 59 orang. Persyaratan yang diajukan tim adalah taruna-taruna yang pernah mengerjakan tugas penggunaan Google Scholar di mata kuliah teknologi informatika saja.

\section{E. Metode Penelitian}

Metode pengumpulan data yang digunakan dalam penelitian ini yaitu melalui metode dokumentasi dan metode kuesioner. Metode dokumentasi yaitu metode yang digunakan untuk pengumpulan data mengenai jumlah populasi penelitian. Sedangkan metode kuesioner yaitu metode yang digunakan untuk mengukur sejauh mana pemanfaatan Google Scholar pada Politeknik IImu Pelayaran Makassar.

Pengolahan data dilakukan dengan metode analisis deskriptif. Teknik analisis deskriptif digunakan untuk memberikan gambaran umum data yang diperoleh dan untuk mendeskripsikan karakteristik responden. Analisis statistik deskriptif yang digunakan meliputi rata-rata dan standar deviasi, median dan modus. Analisis deskriptif berfungsi untuk memberi gambaran sejauh mana Google Scholar telah dimanfaatkan pada Politeknik Ilmu Pelayaran Makassar. Untuk membantu proses pengolahan data secara cepat dan tepat, maka pengolahan data dilakukan melalui program Microsoft Office Excel 2016 Original.

\section{F. Teknik Analisis Data Penelitian}

Penelitian ini menggunakan feasibility study atau studi kelayakan untuk menelaah apakah aplikasi Google Scholar layak diterapkan di Politeknik IImu Pelayaran Makassar. Studi kelayakan meliputi 3 aspek yaitu:

1. Technically feasible

Aspek teknis menghendaki pengujian apakah aplikasi dapat berjalan dengan baik atau tidak. Secara teknis aplikasi ini terbukti dapat berjalan dengan baik sehingga sesuai untuk digunakan dalam mendukung proses persiapan sistem pembelajaran e-learning di Politeknik IImu Pelayaran Makassar.

\section{Economically profitable}


Aspek ekonomi menghendaki pengujian apakah aplikasi dapat membawa keuntungan ekonomi atau tidak. Namun aspek ini tidak selalu mengukur keuntungan dari laba. Tolak ukurnya hanya menguji dampak aplikasi dalam bidang ekonomi. Secara ekonomi aplikasi ini membawa keuntungan ekonomi karena aplikasi ini dapat digunakan secara bebas (gratis) dan hemat biaya. Karena aplikasi ini membantu mengurangi pengeluaran dalam bentuk biaya pengadaan hardcopy buku dan menggantinya dengan e-book serta memudahkan masyarakat untuk menghubungi langsung cendekiawan yang menulis karya tulis tersebut.

3. Socially acceptable

Aspek sosial menghendaki pengujian apakah aplikasi dapat diterima atau tidak secara sosial oleh masyarakat. Secara sosial aplikasi ini dapat diterima oleh masyarakat khususnya di Politeknik IImu Pelayaran Makassar. Hal ini ditunjukkan dengan hasil penelitian ini yang menunjukkan cukup banyaknya civitas akademika di Politeknik IImu Pelayaran Makassar yang menggunakannya. 


\section{HASIL RISET DAN PEMBAHASAN}

\section{A. Deskripsi Data Hasil Penelitian}

Tim peneliti mengelompokkan data riset ini menjadi dua bagian utama. Pertama ialah data tingkat penggunaan Google Scholar di lingkungan akademisi Politeknik IImu Pelayaran Makassar. Kedua ialah data tingkat penguasaan Google Scholar di lingkungan akademisi Politeknik Ilmu Pelayaran Makassar. Hasilnya adalah sebagai berikut:

\section{Tingkat Penggunaan Google Scholar di Politeknik IImu Pelayaran Makassar}

Tim peneliti telah menghitung frekuensi data variable tingkat penggunaan Google Scholar di Politeknik IImu Pelayaran Makassar yang diambil dari 59 responden di aplikasi Microsoft Office Excel 2016 Original. Hasilnya menunjukkan bahwa nilai mean yang diperoleh ialah 64. Nilai mediannya adalah 63. Dan nilai modusnya ialah 63. Sesuai dengan perolehan nilai mean, modus dan median yang tergolong cukup banyak sebenarnya sudah dapat ditarik kesimpulan bahwa jumlah penggunaan Google Scholar tergolong cukup banyak. Artinya jumlah taruna yang memilih kategori cukup banyak adalah sebanyak 24 orang atau $40,68 \%$ dari jumlah populasi penelitian 59 orang. Penjelasan lebih lanjut dapat dilihat, seperti ditunjukkan pada Tabel 3.

Tabel 3. Distribusi Frekuensi Tingkat Penggunaan Google Scholar di Politeknik IImu Pelayaran Makassar

\begin{tabular}{|c|l|r|r|r|r|}
\hline Interval & Kategori & Frekuensi & $\begin{array}{c}\text { Frekuensi } \\
\text { Kumulatif }\end{array}$ & $\begin{array}{c}\text { Persentase } \\
\mathbf{( \% )}\end{array}$ & $\begin{array}{c}\text { Persentase } \\
\text { Kumulatif } \\
(\mathbf{\%})\end{array}$ \\
\hline $86-101$ & Sangat Banyak & 5 & 5 & 8,47 & 8,47 \\
\hline $70-85$ & Banyak & 18 & 23 & 30,51 & 38,98 \\
\hline $53-69$ & Cukup Banyak & 24 & 47 & 40,68 & 79,66 \\
\hline $37-52$ & Kurang & 8 & 55 & 13,56 & 93,22 \\
\hline $21-36$ & Sedikit & 4 & 59 & 6,78 & 100,00 \\
\hline \multicolumn{2}{r|}{ Jumlah } & $\mathbf{5 9}$ & $\mathbf{5 9}$ & $\mathbf{1 0 0}$ & $\mathbf{1 0 0 , 0 0}$ \\
\hline
\end{tabular}

Hasil komputasi variable 1 riset Makmur dan tim dosen tahun 2017 


\section{Tingkat Penguasaan Google Scholar di Politeknik IImu Pelayaran Makassar}

Hasil komputasi data riset mengenai variable tingkat penguasaan Google Scholar di Politeknik IImu Pelayaran Makassar menunjukkan bahwa skor minimum yang diperoleh ialah 2 . Sementara nilai maksimumnya ialah 74 . Nilai mean yang diperoleh adalah 45. Begitupula modus dan median yang diperoleh adalah 45. Hasil komputasi statistik ini menunjukkan bahwa tingkat penguasaan Google Scholar di Politeknik IImu Pelayaran Makassar berada dalam rentang kategori cukup mahir. Artinya jumlah taruna yang memilih kategori cukup mahir adalah sebanyak 26 orang atau $44,07 \%$ dari jumlah populasi penelitian 59 orang.Kesimpulan ini dijelaskan lebih rinci lagi pada Tabel 4.

Tabel 4. Distribusi Frekuensi

Tingkat Penguasaan Google Scholar di Politeknik IImu Pelayaran Makassar

\begin{tabular}{|c|l|r|r|r|r|}
\hline Interval & Kategori & Frekuensi & $\begin{array}{r}\text { Frekuensi } \\
\text { Kumulatif }\end{array}$ & $\begin{array}{c}\text { Persentase } \\
(\mathbf{\%})\end{array}$ & $\begin{array}{c}\text { Persentase } \\
\text { Kumulatif } \\
(\%)\end{array}$ \\
\hline $61-74$ & Sangat Mahir & 10 & 10 & 16,95 & 16,95 \\
\hline $46-60$ & Mahir & 17 & 27 & 28,81 & 45,76 \\
\hline $31-45$ & Cukup Mahir & 26 & 53 & 44,07 & 89,83 \\
\hline $16-30$ & Kurang Mahir & 2 & 55 & 3,39 & 93,22 \\
\hline $2-15$ & Tidak Mahir & 4 & 59 & 6,78 & 100,00 \\
\hline \multicolumn{2}{|r|}{ Jumlah } & $\mathbf{5 9}$ & $\mathbf{5 9}$ & $\mathbf{1 0 0}$ & $\mathbf{1 0 0 , 0 0}$ \\
\hline
\end{tabular}

Hasil komputasi variable 2 riset Makmur dan tim dosen tahun 2017

\section{B. Pembahasan Hasil Penelitian}

Penjelasan lebih lanjut mengenai hasil penelitian ini dibuat dalam bentuk penjelasan komparatif. Tim peneliti sengaja menggunakan grafik agar memudahkan pembaca memahami hasil riset ini. Grafik yang dipilih ialah grafik 3-D pie yang memberikan kemudahan untuk melihat persentasi atau porsi data tiap kategori. Selain itu tim juga telah memilih menggunakan bahasa sederhana untuk mendeskripsikan secara detail maksud dari grafik dalam riset ini. Pembahasan lebih lanjut tentang hasil penelitian dijabarkan sebagai berikut: 
1. Hasil penelitian mengenai tingkat penggunaan Google Scholar di lingkungan akademisi Politeknik Ilmu Pelayaran Makassar. Hasil riset tim peneliti terhadap variable awal penelitian menunjukkan bahwa jumlah penggunaan Google Scholar di Politeknik IImu Pelayaran Makassar tergolong cukup banyak. Atau dengan kata lain belum maksimal. Hal ini tentunya didorong oleh keterbatasan waktu untuk menggunakan fasilitas internet di kampus II Politeknik IImu Pelayaran Makassar. Selain itu masalah lainnya datang dari keterbatasan jumlah laptop yang dimiliki oleh taruna. Hasil riset ini bisa dilihat lebih jelas pada Gambar 2.

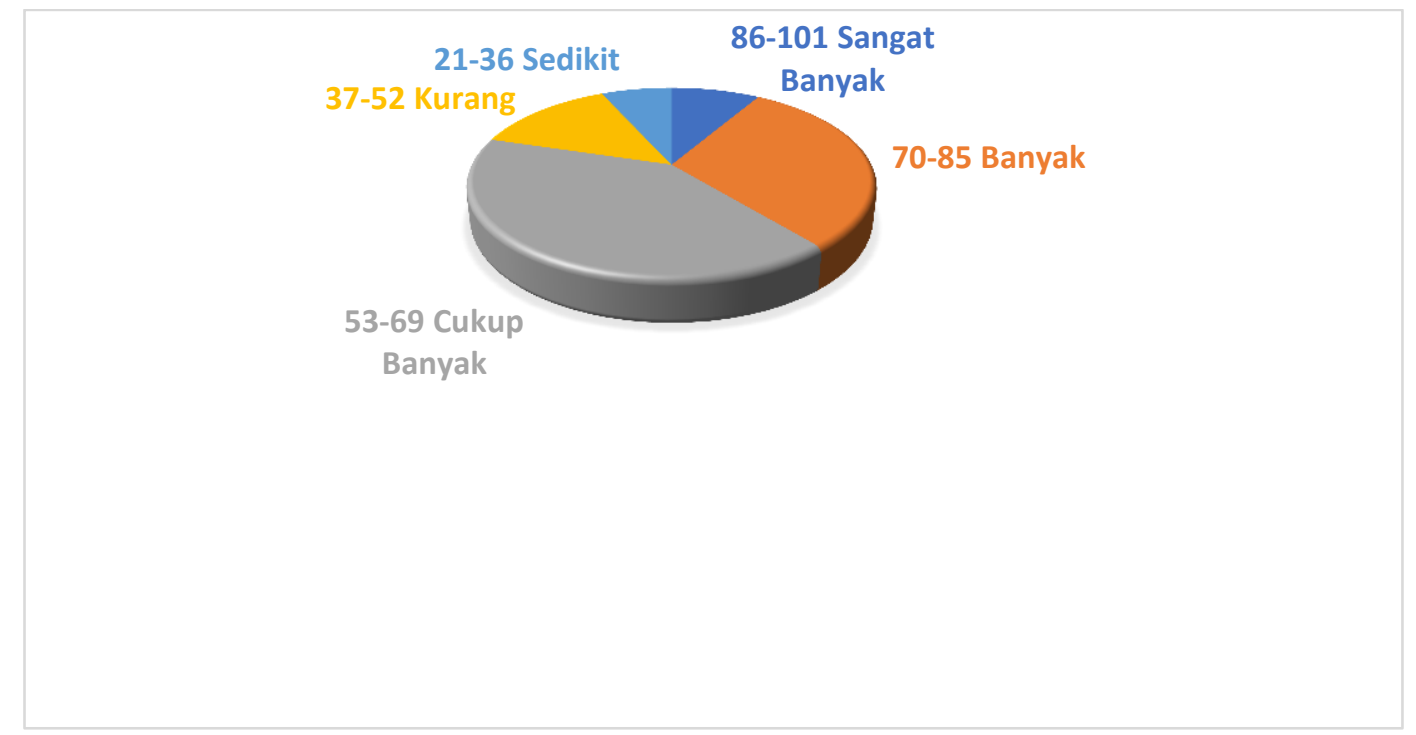

\section{Gambar 2. Grafik Pie Tingkat Penggunaan Google Scholar di Politeknik IImu Pelayaran Makassar}

Hasil ini juga mengindikasikan bahwa jumlah sarana dan prasarana yang mendukung sistem pembelajaran e-learning sudah ada, hanya saja perlu ditambah jumlahnya untuk memaksimalkan jumlah penggunaan google scholar. Sarana yang dimaksud di sini antara lain: jaringan $\mathrm{Wi}-\mathrm{Fi}$, komputer, laptop dan lain-lain. Sementara prasarananya ialah asrama, classroom, aula, laboratorium, perpustakaan dan gedung perkantoran yang dilengkapi dengan hot-spot. Jaringan internet di Politeknik Ilmu Pelayaran Makassar bersumber dari pemancar di kampus I yang terletak di jalan tentara pelajar no.173. Pemancar ini memancarkan sinyal yang ditangkap melalui peralatan di main building kampus II dan dapat digunakan di seluruh area hot spot kampus II. 
Pihak unit teknologi informatika juga telah menambah bandwidth untuk penggunaan internet sehingga jaringan internet lebih leluasa digunakan oleh civitas akademik PIP Makassar. Hal inilah yang mendukung cukup banyaknya jumlah penggunaan google scholar di PIP Makassar.

Tim peneliti juga mengamati bahwa mata kuliah kepelautan, teknologi informatika, bahasa inggris, dan metodologi penelitian serta karya ilmiah terapan benar-benar membutuhkan aplikasi. Hal ini didasarkan pada pertimbangan banyaknya literatur yang dibutuhkan oleh mata kuliah-mata kuliah tersebut. Selain itu kemudahan berkomunikasi dengan cendekiawan yang disediakan oleh aplikasi ini benar-benar akan sangat membantu pembelajaran mata kuliah-mata kuliah tersebut. Sehingga dosen pengampu matkul-matkul tersebut tidak kewalahan melayani pertanyaan dari tarunanya.

\section{Hasil Penelitian mengenai tingkat penguasaan Google Scholar} di lingkungan akademisi Politeknik IImu Pelayaran Makassar

Hasil riset tim peneliti terhadap variable awal penelitian menunjukkan bahwa tingkat kemahiran taruna dan dosen Politeknik IImu Pelayaran Makassar dalam menggunakan Google Scholar tergolong cukup mahir. Atau dalam bahasa sederhananya dianggap belum maksimal. Padahal sebenarnya pelatihan tentang penggunaan aplikasi ini di lingkungan dosen Politeknik IImu Pelayaran Makassar sudah pernah diadakan. Berarti masalahnya disebabkan oleh keterbatasan biaya dan waktu dosen dan taruna untuk menggunakan fasilitas Google Scholar di kampus II Politeknik IImu Pelayaran Makassar. Selain itu masalah lainnya datang dari keterbatasan jumlah laptop yang dimiliki oleh taruna untuk menggunakan aplikasi ini. Hasil riset ini bisa dilihat lebih jelas pada Gambar 3. 


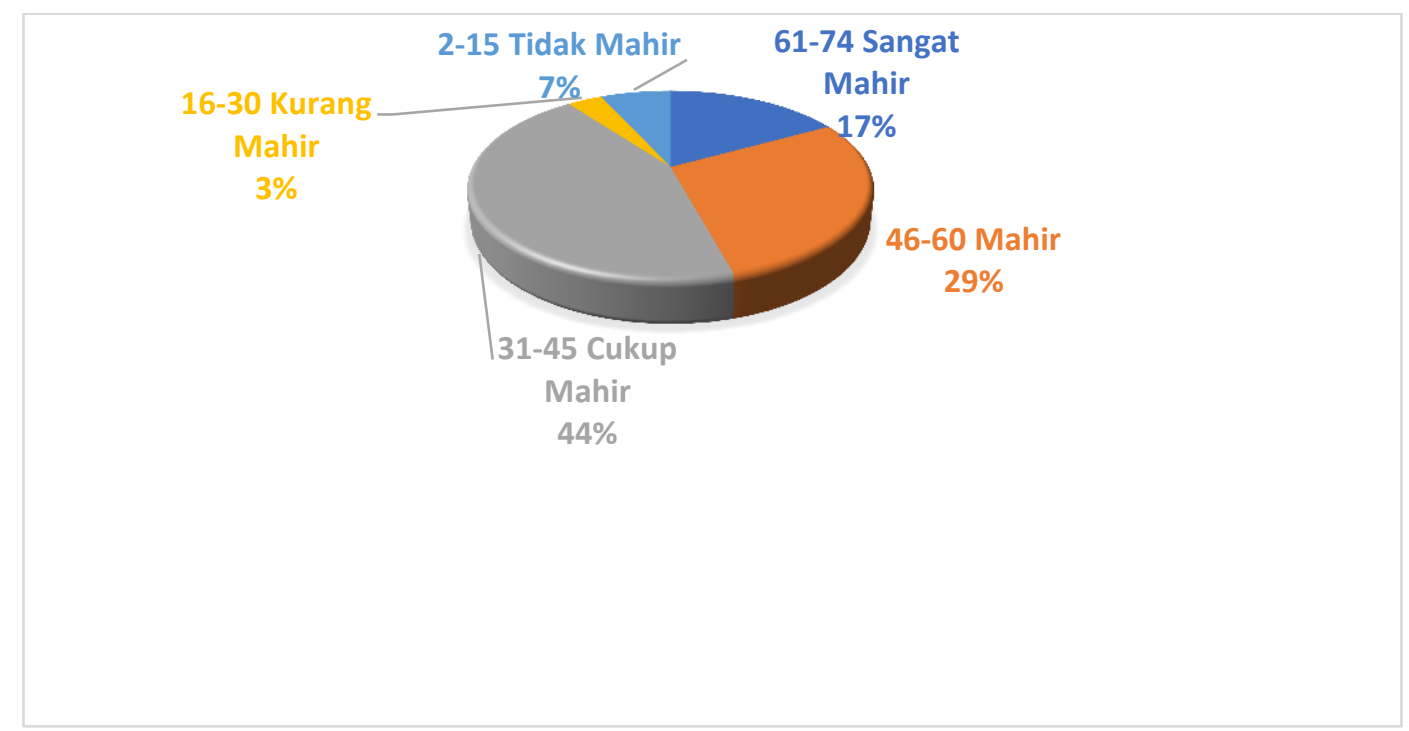

\section{Gambar 3. Grafik Pie Tingkat Penguasaan Google Scholar di Politeknik IImu Pelayaran Makassar}

\section{PENUTUP}

\section{A. Kesimpulan}

Merujuk pada kajian pustaka dan hasil riset yang telah dijabarkan sebelumnya, maka tim peneliti memberikan simpulan sebagai berikut:

1. Umumnya tingkat penggunaan Google Scholar di Politeknik IImu Pelayaran Makassar tergolong cukup banyak dilihat dari indikator jumlah pengguna, mata kuliah, tulisan berliteratur akademis Google Scholar, jurnal terpublikasi pada Google Scholar, kesesuaiannya sebagai sumber literatur akademis secara teknis, ekonomi maupun sosial.

2. Umumnya tingkat penguasaan Google Scholar di Politeknik IImu Pelayaran Makassar tergolong cukup mahir dilihat dari indikator tingkat penguasaan dosen dan taruna dalam mencari literatur akademis di Google Scholar dibandingkan dengan aplikasi lainnya seperti search engine, portal universitas, scribd, e-book, e-paper, dan kesesuaiannya baik secara teknis, ekonomi maupun sosial. 


\section{B. Saran Tim Peneliti}

Berdasarkan kesimpulan hasil penelitian yang telah dikemukakan sebelumnya, berikut ini akan diajukan beberapa saran oleh tim peneliti:

1. Mempertahankan fasilitas internet di Politeknik IImu Pelayaran Makassar Makassar yang sudah baik serta meningkatkannya agar dapat mencapai hasil yang maksimal.

2. Menambah jaringan internet di Kampus Politeknik IImu Pelayaran Makassar.

3. Memperbanyak izin penggunaan laptop pribadi taruna di Kampus II Politeknik IImu Pelayaran Makassar. 


\section{DAFTAR PUSTAKA}

Dahar, Ratna Wilis. (2006). Teori-Teori Belajar dan Pembelajaran. Buku diterbitkan pada tahun 2011. Penerbit Erlangga, Jakarta.

Ali, M. (2009). Pengembangan Media Pembelajaran Interaktif Mata Kuliah Medan Elektromagnetik Universitas Negeri Yogyakarta. Jurnal Edukasi Vol. 5 No. 1. Yogyakarta: , 3.

H.J. Gino, Suwarni, Suripto, Maryanto, Sutijan. (2000). Belajar dan Pembelajaran I. Surakarta: Penerbit. UNS Press.

Komalasari, K. (2011). Pembelajaran Kontekstual Konsep dan Aplikasi. Bandung: PT Refika Aditama.

Ni Ketut Susrini (2009). Google. B First. p. 113. ISBN 978-979-24-3840-6

Pupuh Fathurrohman \& dkk. (2013). Pengembangan Pendidikan Karakter. Bandung: PT. Refika Aditama.

Sanjaya, W. (2006). Strategi Pembelajaran. Jakarta: Penerbit. Kencana Prenada Media Group.

Siahaan, S. (2004). E-Learning (Pembelajaran Elektronik) sebagai Salah Alternatif Kegiatan Pembelajaran. Jurnal Pendidikan , 42.

Sudirman, S. (2007, Mei senin). E-learning (Pembelajaran Elektronik) Sebagai Salah Satu Alternatif Kegiatan Pembelajaran. Dipetik April Selasa, 2017, dari E-learning (Pembelajaran Elektronik) Sebagai Salah Satu Alternatif Kegiatan Pembelajaran: http://www.balitbang.org

Sugandi, A. (2000). Teori Pembelajaran. Bandung: PTenerbit. Remaja Rosdakarya.

Sugiono. (2009). Metedologi penelitian. Bandung : Alfabeta.

Sukintaka. (2004). Teori Pendidikan Jasmani Filosofi Pembelajaran dan Masa Depan. Bandung : Penerbit. Yayasan Nuansa Cendikia.

Valiant, N. (2013, Mei Jumat). Google Scholar. Dipetik 11 Selasa, 2017, dari Google Scholar: http:// minniemickie.blogspot.co.id/ 2013/05/apa-itugoogle-scholar.html

Waller, V. a. (2001, October 2001 Rabu). A Definition for E-Learning" in Newsletter of Open and Distance Learning Quality Control. Dipetik April 
Selasa, 2017, dari A Definition for E-Learning" in Newsletter of Open and Distance Learning Quality Control.: http://www.odlqc.org.uk/odlqc/n19-e.html 